\title{
Election System of Bosnia and Herzegovina: Catalyst of Unsuccesful Democratization
}

\author{
Adis Arapovic, Bedrudin Brljavac \\ University of Sarajevo, Bosnia and Herzegovina \\ Disagreements and fights mainly ensue \\ when those who are equal do not receive an equal share, \\ or, when those who are not equal receive an equal share.
}

\section{Introduction}

ARISTOTLE

After the ruling of the European Court of Human Rights in the case of 'Sejdic\&Finci vs. Bosnia and Herzegovina', it is evident that election system of Bosnia and Herzegovina is discriminatory and that it is necessary to conduct systematic reform of this area, in order to satisfy the basic principles of contemporary democratic election systems, and in order to make election system, together with the B\&H Constitution, compatible with the European Convention On Protection Of Human Rights And Fundamental Freedoms.

Present $\mathrm{B} \& \mathrm{H}$ election system, as this work will show, is not completely grounded in general, equal and secret right to vote and direct election for all citizens of $\mathrm{B} \& \mathrm{H}$ who have a voting right. However, B\&H election system has contributed towards establishment of the rule of law, democratization and legitimate political pluralism in the last decade. B\&H election system has not achieved the standard of contemporary democratic standards which assume five principles: secrecy of voting, free elections, direct elections, equal voting right, and general right to vote.

Unfinished election system has contributed to breach of constitution principles and international conventions on human rights, frequent political crisis, unstable parliamentary majorities, malversations and misuses in election process, slow or blocked implementation of election results, breach of election rights etc. This 
work, through combining of theoretical, empirical and policy study, with dominant use of critical content analysis, offers unique hypothesis that B\&H election system is catalyst of unsuccessful democratization, and as such implies slowed or blocked process of consolidation of parliamentary democracy, and democratization of society in general.

\section{Basic features of election system of Bosnia and Herzegovina}

Approaches to study of election systems are different. Still, large majority of these approaches has few common denominators or subjects of research, such as 'structure, classification and effects of elections systems, while significant attention is being given to distribution of election circles, election candidature, voting and especially to method of counting votes into mandates and consequential political outcomes of $\mathrm{it}^{11}$. It follows from this that election system can be defined in two ways, that is, in broader and in narrower sense. 'In a broader sense, under this term we assume an array of all rules and actions which are regulated by legislation of a country, and which relate to elections and election law. In the narrower sense, under the term of election system, we assume one of its elements, and that is election formula, or ways of distributing mandates. ${ }^{2}$

'Research of election law and election systems is by rule macropoliticaly directed: behavior of voters and distribution of votes has a meaning only if it influences directions of election law and election system, or vice versa, if election law and election system has structured effects on voters choices' ${ }^{\prime 3}$. Exactly this role of election system, that all its good and especially bad features have crucial impact on voters choices, demonstrate themselves drastically in $\mathrm{B} \& \mathrm{H}$ in the last decade, and as such have had dramatic consequences on direction of democratization, political and social pluralism.

'Election system is systematically governed by legal norms (constitution law, election law, election legislation), that is, by Constitution, laws and other rules and sometimes also by custom norms, conventions and agreements between major actors of election. In contemporary political systems election into highest representative bodies is by rule regulated by constitutions, by which it stresses the importance that elections have in every democratic political order. ${ }^{14}$

Basic role of election system in democratically organized state is creating of institutional frame through which democratic order, transparency of election process and holding of free and fair elections in the whole country will be 
promoted and strengthened. Some of the leading authorities of contemporary politology such as Arend Lijphart and Giovanni Sartori stress out that election system is very important segment of political system and that its shape fundamentally determines its functioning. Lijphart describes election system as the most important element of representative democracy, while Sartori considers that election system is the most important part of influence of political system.

Features of the election system have an 'enormous importance in the overall election process, and election legislation, by which election system is legally and politically legitimized and constituted, and as such represent the fundamental legalpolitical framework of constitutional importance. Subsequently, election system represents inseparable part of constitutional and political system of every country, or in other words, an indicator of reached democratic level of social order. Election system is feature of execution of power, way of realization of principle of national sovereignty, and mechanism of realization of political representation, especially in the systems in which elected political representatives are responsible to electorate, in which those representatives, by holding free mandate execute general wants of the electorate. ${ }^{5}$

Election system is not only an empty framework and its importance for the election results should not be neglected, which is especially indicative in the example of $\mathrm{B} \& \mathrm{H}$. Because of this it is important to be reminded that once formed, election system begins to generate very important and long term consequences. Election system is especially important for stability of society, or in other words, incompleteness and anomalies of election system can be an agens of instability of society.

Majority of theoreticians agree that election system fundamentally represents 'institutional modus inside of which voters express their political preferences in the form of votes and inside of which votes of electorate are converted into mandates. ${ }^{16}$ Election system is in fact part of the broader election law, which in itself contains election framework (majority or proportional), election units, election competition, voting, methods of converting votes into mandates and election census. The very system encompasses the election formulas, calculation of distribution of mandates, structure of voting ballots, magnitude of election units, registration of voters, organization of elections and confirmation of political subjects. The most common way of grouping election systems is according to how they convert votes into parliamentary places, that is, how proportional they are. Therefore, it is impossible to imagine development of constitutional, parliamentary, democratic state without well organized election system, which will at the same time reflect the context and 
ambient of a certain society, and in clear fashion define organization and execution of election in a particular country.

In Bosnia and Herzegovina proportional election system has been established with majority number of multimandate units, which is to the largest part conditioned by complicated political system, that is, constitutional architecture of B\&H. Namely, 'mostly due to two entity model, which is accompanied by multy-member election unit, it was necessary to establish concurrent existence of proportional and compensational election system ${ }^{71}$. Thanks to compensational election system two levels of election census have been mixed (from 3-5\%), with original 'goal of ensuring total equality of all three constitutional Bosnian nationalities, Bosniaks, Serbs and Croats, in conditions when return of their members to their pre-war places of residence has not been at the satisfactory level, in almost all parts of Bosnia and Herzegovina. ${ }^{18}$

Legal and political framework of B\&H is quite complicated given that it maintains certain sui generis constitutional solutions. B\&H Constitution is annex to General Framework of Peace Agreement from 1995 (Dayton Agreement). Constitution gives certain powers to state institutions, while majority of powers are given to entities: Federation of Bosnia and Herzegovina (FB\&H) and Republic of Srpska (RS), as well as cantons, as administrative units in FB\&H. In the same manner, District of Brcko maintains a special status as a unit of local self-rule, under the sovereignty of B\&H. Dayton agreement has established the Office of High Representative (OHR), which has significant powers and, de facto, is part of constitutional structure.

B\&H Constitution recognizes Bosniaks, Croats and Serbs as 'constitutional nations'. By later decision of the B\&H Constitutional Court from year 2000, these three nations have been recognized as constitutional on all territory of $\mathrm{B} \& \mathrm{H}$, which was supposed to have ensured equality. Those citizens of B\&H which do not proclaim themselves in the context of nationality are referred to as 'Others'. Such conceptual postulate that legitimizes three ethnic collectivities as political nations, and all other ethnic groups, national minorities, undecided and finally citizens, as 'others', secondary or marginal socio-political capital, has generated ethnic homogenization in the last decade, permanent inter-ethnic tension, and latent conflict between so called national and citizen ideologies.

$\mathrm{B} \& \mathrm{H}$ today is unique in the world according to its state, political and legal order. Its order is in significant part of a republican type, even though B\&H does not function nor defines itself as a republic, among else, due to the complexity of the political system and its parts (entities and cantons), which characterize federalist 
systems. Prefix 'republic' was lost by signing of Dayton Peace Agreement in year 1995 and its constitutional annex, so that today's B\&H is one of the rare countries which does not have a political-legal attribute to its name, among else because of de iure and de facto synthetization of elements of republican and federalist political system.

The state comprises of one republic and one federation and one state-district. Theory of political systems, and especially international practice, does not recognize such political-legal structure, and the same is primarily the consequence of the process of war ending and establishment of political agreement on the common state. Additional elements of complexity are the facts that neither Federation of $\mathrm{B} \& \mathrm{H}$, nor Republic of Srpska do not have integrated territory, and that Federation of $\mathrm{B} \& \mathrm{H}$ is constituted by 10 cantons with very high jurisdictions, own legislation, executive and judicial powers, revenues etc.

In institutional sense, $\mathrm{B} \& \mathrm{H}$ has, vertically asymmetric, 3 viewed from the perspective of RS, or 4 viewed from perspective of FB\&H, levels of state, which is also uncommon practice in theory and practice of political systems.

Highest, state institutional level, in legislative sense is made up of two house Parliamentary Assembly of B\&H, with lower, Representative Assembly and upper, National Assembly. Executive power of this level is made up of three-member Presidency with equal status of its members, with Council of Ministers (which does not have jurisdictions of the state), made up of 9 ministers, that is 9 ministers and President of the Council of Ministers. State level also has part of the jurisdictions inside the judicial powers, through the Court of B\&H as a criminal court and Constitutional Court of $\mathrm{B} \& \mathrm{H}$, which in fact does not have sovereign jurisdictions in interpretation of $\mathrm{B} \& \mathrm{H}$ Constitution, but compatibility and harmonization of lower legal acts with the B\&H Constitution, while interpretation of the Constitution is entrusted to OHR.

Entities have its own three layered division of the powers, where in RS also exists People Assembly, with quazi-two assembly system, as the People Assembly in RS is not upper house of the Assembly, as it does not have jurisdictions which these assemblies usually have, as it is the case with the state, and federal parliament and its people assembly, so that this is obviously one more asymmetry in the direct connection with the election system. Besides legislative, entities have and executive powers, which in RS is especially centralized, even though part of the jurisdictions is shared with the state level (for example fiscal policy, justice and communication etc.) while the remaining typical republic jurisdictions such as education, healthcare, social policy and alike with poor jurisdictions of local self 
rule i.e. municipalities. In Federation of B\&H, part of jurisdictions is shared with the cantons (education, culture, spatial regulation, social politics etc.), with also low level of autonomy of local self-rule, that is, cities and municipalities.

District of Brcko, as corpus separatum, initially under international control, by Constitutional changes of 2009 is under jurisdiction of state of $\mathrm{B} \& \mathrm{H}$, that is, outside of jurisdictions of the entities, also having its own legislative and executive powers, with existence of basic criminal courts.

Key anomaly of political system of B\&H is existence of OHR, which by Dayton peace agreement was temporarily integrated into political system of $\mathrm{B} \& \mathrm{H}$, is assigned as mechanism of political presence of international community in execution of this agreement, as the supreme interpreter of constitutional provisions. By provisions of Dayton peace agreement, OHR has significant legislative, executive and judicial powers, while domestic legal instances and individuals do not have a right of appellation on decisions of OHR. Generally viewed, presence and jurisdictions of OHR undoubtedly reduces sovereignty of $\mathrm{B} \& \mathrm{H}$, and degenerate political responsibility of domestic institutions and political representatives.

Such a complex political system is without a parallel in international theory and practice of political systems, and is especially pronounced factor of determining of overall political relationships. Election system by this contains all complexity of legal-political system, and besides that, contains its own instruments in function of democratization and equality, even though in array of cases there are inconsistencies which additionally complicates the picture of legal-political order.

As previously mentioned, Parliamentary Assembly of B\&H is bicameral and it is comprised of two houses- House of People and House of Representatives. House of People of Parliamentary Assembly of B\&H, as an upper house of the parliament, is made up of 15 delegates, from whom 10 are elected in House of People of FB\&H (five Bosniaks and five Croats), and five in National Assembly of Republic of Srpska (5 Serbs). In the process of election of representatives, in Representative, lower house of Parliamentary Assembly of B\&H from total 42 places, 28 places belong to FB\&H and 14 to RS. When choosing representatives from FB\&H members of state parliament are chosen in multimandate units, where 21 representatives are chosen using proportional election system with use of SaintLague method of redistribution of mandates and census of 3\%. Remaining 7 mandates are compensational mandates, and in their distribution Saint-Lague method is used with census of $5 \%$. According to the same election principle remaining 14 representative mandates from RS are distributed, in a way that 9 
representatives are chosen using the proportional election system, while remaining 5 are chosen based on compensational election system.

Furthermore, Representative, lower house of Parliament of FB\&H is made up of 98 representatives, out of which every constitutional nationality obtains at least four mandates. There are no minimal quotas for members of non-constitutional nationalities. If political parties do not win at least 4 mandates for members of every constitutional nationality, compensational list of mandates is formed. Compensation mandates are later on distributed in a way that minimal number of mandates for members of 3 constitutional nationalities is distributed between political parties and coalitions which have participated in the electoral process, without regard to the number of obtained votes. Similar solutions are used when choosing 83 representatives in the National Assembly of RS. Assignment of mandates for cantonal assemblies is performed according to the system of proportional representation, without compensational mandates. It is clear that in the system of mandate distribution, there is pronounced measure of protection of collective ethnic interests, opposed to citizen sovereignty and protection of individual rights and interests, including equal, active and passive right.

Discriminatory position of members of so called non-constitutional nations, is especially pronounced in houses of people as upper houses of legislative organs at the state and entity levels. Ruling of the European Court for Human Rights (ECHR) in the subject of 'Sejdic \& Finci vs. B\&H' directly establishes that the way of electing delegates to the House of People in Parliamentary Assembly of B\&H and the way of election of members of Presidency of B\&H is 'discriminatory, that members of ${ }^{9}$, so called non-constitutional nationalities are not ensured passive (or equal) election rights', and as such that it is opposed to the European Convention on Protection of Human Rights and Fundamental Freedoms, that is, its Protocols 1 and 12 .

Presidency of B\&H is collective chief of the country, made up of three members, from three constitutional nations, where voters from FB\&H choose only members of Presidency of Bosniaks and Croat nationalities, while voters in RS choose only a member of Serb nationality. By this voters from FB\&H can choose only 2 out of 3 , while voters in RS only 1 out of 3 members. This confirms the earlier expressed thesis on ethnic reduction of passive voter rights, as candidates who want to contest for the member of the Presidency have to be residents of the entity in which member of the Presidency is chosen. In simple language, Serb from FB\&H, and Croat or Bosniaks from RS, cannot be chosen for members of Presidency of B\&H, besides which all citizens who are not declared as Bosniaks, Serbs or Croats, also 
can not be chosen into Presidency of B\&H. This anomaly is also treated by ruling of the ECHR in the case of 'Sejdic \& Finci'.

In a summary, way of election of members of Presidency of B\&H, as well as the choice of delegates into House of People of Parliamentary Assembly of B\&H prevents the members of 'non-constitutional' nationalities, national minorities and undecided to nominate themselves as candidates or to be chosen into these bodies, which by the ruling of ECHR in the case of 'Sejdic \& Finci' has been labeled as against European Convention on Protection of Human Rights, and as such has to be changed and harmonized with this Convention.

Furthermore, members of national minorities have a right to representation only in local bodies, with respect to municipal council and city council proportional to percentage of their participation in population according to the latest census in B\&H in year of 1991, even though these injunctions are massively breached in practice, due to which representation of national minorities is much lower from obligatory norms, and even where it exists, it is often in the interest of bigger parties, and not in the interest of particular population of national minority.

Ownership of such mandate belongs to elected owner of the mandate, and not the party or coalition on behalf of which candidature is nominated. There is legal obligation that the candidate lists have minimum $30 \%$ of candidates of lesser represented gender, or more precisely 1 out of 3,2 out of 5,3 out of 8 etc. candidates of the nominated candidates on the lists. Even though this norm is nominally respected when nominating candidate lists, preferential closed lists, patriarchal inheritance, lower percent of voting women compared to man, and unequal participation of women in pre-election and promotional activities of the parties, have led to condition where on average less than $20 \%$ of women is directly chosen into legislative bodies, while the proportion of women nominated into executive bodies is significantly lower. By this we enhance one more shape of discrimination, besides earlier mentioned ethnic and territorial belonging, this time electoral discrimination based on gender basis.

We can sum up that $\mathrm{B} \& \mathrm{H}$ election system is defined by specific provisions of $\mathrm{B} \& \mathrm{H}$ Constitution, and lower levels of power, as well as by set of election legislation comprised of Election Law of $\mathrm{B} \& \mathrm{H}$, and 12 laws at state and entity levels. Also, constitutions of entities, cantors, statutes of municipalities also can be considered as part of $\mathrm{B} \& \mathrm{H}$ election system.B\&H election system is combination of almost all known election principles: majority principle and one-member election unit for the election of Presidency of $\mathrm{B} \& \mathrm{H}$, then proportional principle for multimember election unit for the choice of parliament members, census of $3 \%$ for 
ordinary mandates through closed preferential lists, preferential voting (lists opened to voters), and census of 5\% for compensational mandates, because of which $\mathrm{B} \& \mathrm{H}$ election system can be considered combined or hybrid sui generis election system.

Even though function of election is to, among else, 'ensure representation and establish legitimacy', in order to 'channel demands of people to the government', because, even 'authoritarian regimes maintain elections even when these are not competitive ${ }^{10}, \mathrm{~B} \& \mathrm{H}$ election system, even though it nominally contains some elements of liberal-democratic tradition of pluralism, equally contains and extreme recidivism of totalitarianism, and political, ethnic, territorial and gender discrimination.

\section{B\&H Election System as Agens of Political Crisis}

Last general, presidential and parliamentary elections in B\&H were held on 3rd of October 2010. General elections, according to stand of international institutions, were held in very complicated election system. 63 political subjects were registered or 30 political parties were contesting in these elections, 11 coalitions of political parties and 13 independent candidates. There were total 8.242 candidates on the lists, who contested for 518 mandates. Electorate body numbered 3.1 million of voters. Election turnout was $56.52 \%$ or 1.770 .388 voters. Election expenses amounted to 6.5 million EUR. ${ }^{11}$

$\mathrm{B} \& \mathrm{H}$ Election system was characterized as 'very complicated and as such it represented the challenge in terms of understanding and execution for all participants in the election process ${ }^{\prime 12}$. General opinion is that 'elections were executed in accordance with the norms of OSCE and Council of Europe, but certain key areas and election questions require further action and necessary corrections. And besides the fact that existing legal framework offers satisfactory basis for organizing of democratic and fair elections, the same is still, in the clear form, containing ethnically based limitations and restrictions with respect to democratic right to candidature. This kind of structure explicitly represents the breach of European Convention on Human Rights and legally binding decisions of European Court of Human Rights (ECHR), as well as obligations towards OSCE. ${ }^{13}$

'General remark for pre-election rhetoric, relating to obligations of candidates to ethical, constitutional and legal behavior during preelection campaign, is mainly negative. The amount of registered media announcements with elements of negative rhetorics, 
accompanied by negative rhetorics inside the highest legislative bodies, and especially during pre-election relies of political parties, in combination with frequent negative newspaper comments, had predetermined negative cumulative impression of the campaign, political party public appearances and those of individual candidates. $^{14}$

'Ethnic divisions, and ethnic and entity based polarization were once more main characteristics of pre-election public discourse in $\mathrm{B} \& \mathrm{H}$. For example, due to constitutional obstacles and legal limitations, on voting right which is reduced based on place of residence, entity and ethnic belonging, majority of political subjects have continued with the trend of addressing mainly its own ethnic community. ${ }^{15}$

One research conducted before elections, had for its aim checking of distribution of electorate body based on national subsets, which generates choice of voters according to parties which advocate exclusive or dominantly one national support, but also commitment of the political parties to act mainly towards one-national voting body. According to this research ' $88 \%$ of the voters in $\mathrm{B} \& \mathrm{H}$ votes for political parties which have dominant support of one-national voting body, which is significantly more than in the first multiparty elections in 1990. Results of this research have been confirmed by the results of the last elections as well, so that it can be claimed that over $90 \%$ of parliamentary parties had exclusively or dominantly one-national voting body. ${ }^{16}$

$\mathrm{B} \& \mathrm{H}$ has subscribed to respect the equality of genders based on few international agreements, which have been stated in B\&H Constitution, including UN Convention on Elimination of all Forms of Discrimination Against Women (CEDAW). Also, B\&H Law on gender equality ensures equal participation of women in all levels of power, including legislative and executive bodies. OSCE stresses that 'legal conditions connected with gender balance on party candidate lists have been respected and that $37.7 \%$ of candidates in election process were of female gender. However, only around $19 \%$ of women were chosen into three parliaments at state and entity levels. Total of two women compared to seventeen man contested for Presidency of B\&H, and one woman compared to eighteen man for Presidency in RS. However, neither of mentioned woman candidates was not elected in either of these presidential races. ${ }^{17}$ From 8.242 totally verified candidates, $63.1 \%$ or 5.201 candidates were man, and $36.9 \%$ or 3.035 were women. ${ }^{18}$ 
With respect to minority groups, it has been clearly shown that this population is in very marginalized and discriminated position. Namely, in B\&H it has been recognized that there are seventeen ethic minority groups as national minorities. The most numerous and to the public known minority are Roma with around 9.000 people according to the census in 1991. However, it is considered that their actual number is significantly higher, and estimates are somewhere between 50.000 and 100.000 members. Still, besides 'the fact that this group of citizens is most represented in $\mathrm{B} \& \mathrm{H}$, they are, together with members of other minorities, in very unequal position and marginalized part of society in every sense, whether economic, political, educational etc. There are even examples where unknown number of voters who are members of Roma population is unknown because they do not posses personal identification documents and citizenship. During General elections of 2010 from 8.242 candidates that contested in election race only one candidate was an official representative of minority, 139 were from 'others', and 28 'undecided' ${ }^{19}$.

One of neuralgic spots of elections held in 2010 were so called invalid ballots. Final total percent of invalid ballots was $7,97 \%$, while invalid ballots relating to Presidency of B\&H member from RS was $9,86 \%$, and for the member of Bosnian Presidency of $\mathrm{B} \& \mathrm{H}$ member from FB\&H 6,82\%, which is dramatically above the European average. Data lead to conclusion that the number of invalid ballots, besides all other anomalies, additionally endangers the trust into election process.

After the pronouncement of election results activities of political parties on forming parliamentary majority and constituting of legislative and executive power on state, entity and canton level had started.

SDP and SDA have advocated integral constitution of government on cantonal, federal and state level around the acceptance of the 'platform' on program cooperation basis, while HDZ B\&H and HDZ 1990 have advocated participation in government based on election legitimacy and dominant preference of Croatian voters, that is forming of the government based on ethnic legitimacy (or exclusivity) and not mathematical majorities. SNSD and SDS have been giving support to Croatian party block and were waiting post-election epilogue on the federal government level. Finally, House of Representatives of FB\&H Parliament was constituted and incomplete House of People of FB\&H Parliament and Federal Government was formed, whose constitution and election was disputed by two HDZ by objection to the Central Election Commission and B\&H Constitutional Court. 
Decision of Central Election Commission on illegality of such election of federal government institutions, by the end of March 2011., were suspended by High Representative (OHR), after which HDZ B\&H has withdrawn its request for Court decision on constitutionality of federal government, by which the longest postelection crisis in post-war B\&H has started.

After a number of unsuccessful negotiations, ineffective international pressure, growing inter-party and ethnic tensions, and after more than 400 days from elections, at the very end of 2011 political agreement was reached between three two-party blocks (SDA B\&H/SDP, HDZ B\&H/HDZ 1990, SNSD/SDS) about distribution of minister positions in the future government composition, with which forming of government was deblocked on a state level and full implementation of the election results was approaching the end, even though disputing of legitimacy of Government of FB\&H still lasts.

International community has expressed in numerous occasions serious concern with respect to political paralysis in which $\mathrm{B} \& \mathrm{H}$ is found, stressing that this may be the most serious political crisis since the peace agreement of 1995 was signed. For example, Parliamentary Assembly of Council of Europe, in October 2011 has adopted a Resolution on political situation in the Balkans. In the resolution it pointed out to all negative consequences of delay in forming Council of Ministers of $\mathrm{B} \& \mathrm{H}$ and expresses the concern over non-execution of necessary reforms for continuing of euro integration path of $\mathrm{B} \& \mathrm{H}$.

'A year after the elections, $B \& H$ still does not have a government which represents the longest political crisis of the country after the end of the war in 1995. In this report and resolution the urgent need for solution of political dead-end is expressed. It is necessary to form the government in order to execute needed reforms on the state level. This would open perspective of European integration of the country and improve regional cooperation ${ }^{201}$, it is stated in the resolution.

Council of Ministers of European Union, in one of its conclusions has called upon leaders in B\&H to form the new assembly of ministers in order to initiate the reforms necessary for qualitative advancement towards the European Union. Ministers of foreign affairs of the member states of EU have expressed serious concern, as they consider that in B\&H prevails 'continuous political dead-end', which prevents normal functioning of the state and process of European integrations. Concurrent with opinions of official Bruxelles, European officials in $\mathrm{B} \& \mathrm{H}$ have many times expressed concern because of impossibility of achieving 
agreement in connection with the Council of Ministers, but also implementation of ruling of ECHR in the subject of 'Sejdic\&Finci'.

International rating agency Standard \& Poor's' has lowered credit rating of B\&H during 2011 with an opinion that political flexibility has deteriorated, with ever worsening political environment, which is observed in lower prospective for solving political crisis in $\mathrm{B} \& \mathrm{H}$. This reflects in absence of improvement in adoption of state budget for 2011 and 2012 and lack of forming of government 13 months after the elections.

During 2011 we could hear the stands and analysis of certain domestic and foreign think-tanks in the public discourse that situation can lead to open conflict and disintegration of the country, if the political tensions and social polarization with which $\mathrm{B} \& \mathrm{H}$ society is faced today is continued.

One of the interpretations of permanent political crisis and blockade of forming of government after the 2010 elections is that conflict of two political concepts is on the scene. Namely, Bosnian political space, besides other conflicts, is scene of ideological conflict of two concepts relating to the way of forming of government and functioning of the government in general. Strict ethnic concept of government does not recognize democratic fact that in the last elections in B\&H large support of the citizens received different politics which does not view B\&H as a sum of all nations which live in it, but as a state of equal citizens. Simply, conflict of these two concepts is conflict of primacy of collective ethno-national sovereignty, as opposed to individual citizen sovereignty. In the same manner that ethno-national political circles dispute political legitimacy to multy-ethnic parties, the so called citizen or non-ethnic parties ignore the fact that exclusivity of ethnic political representation is characteristic of $\mathrm{B} \& \mathrm{H}$ Constitution, and on these premises, Election law that is in force. Consequence of the above is continued presence of pronounced conservative nationalism based on particular ethnic patriotism, where political elites, artfully manipulating through fear, hypothesize 'that nation is threatened with certain internal or external danger ${ }^{121}$, from the other ethnic or national group. On top of this, evident is the presence of elements of 'expansionary nationalism ${ }^{122}$, mainly through the segments of political elites and mainstream media, infused from Serbia and to smaller extent from Croatia.

\section{Stable Stagnation or Uncertain Reform}

Even though until now a large number of changes have been made to election system, especially to Election Law of B\&H, there are still serious obstacles which 
slow down consolidation of parliamentary democracy and functioning of election system based on principles of free elections: secrecy and freedom of vote, direct and indirect election, and equal voting right and general voting right.

Namely, in the very Election Law of B\&H there is a number of serious deficiencies, incompleteness, contradictory provisions and anomalies which, cumulatively, to a serious extent endanger maintaining of transparent, democratic, fair and just elections, where every citizen of $\mathrm{B} \& \mathrm{H}$ would have equal right and possibility to choose its representatives or to be chosen.B\&H election system is still in large part reflecting dominance or supremacy of ethnic collectivities in relation to individual or citizen, in a way that its meaning and the role is understood in stable societies of parliamentary democracies. Of course, election system is determined by provisions and principles on which constitutional order of $\mathrm{B} \& \mathrm{H}$ is based, so that every critique of election system is in fact beginning by critique of constitutional order.

However, analyzing of actual B\&H election system, it can be concluded that there are number of deficiencies which primarily dispute active and passive voting right, and encourage inequality and discrimination. We can conclude that election system, more precisely election right is based on ethnic and territorial belonging, which is opposite to $\mathrm{B} \& \mathrm{H}$ Constitution, which insists on protection of individual human rights. However, as a final result, political rights in B\&H in this way do not represent individual rights of every citizen or individuals but are more rights of collective, which additionally, in the case of $\mathrm{B} \& \mathrm{H}$, are collective rights guaranteed only to the members of the three largest national groups in the country, or three constitutive nations. In fact, democratic principle of equal voting right in $\mathrm{B} \& \mathrm{H}$ is not achieved, as passive voting right is breached in multiple ways (by limiting right of candidature to certain territory and on belonging to certain nation), and active voting right (through limiting of choice of candidates of only certain nationality and from certain territory). Absence of rights of part of voting body from District of Brcko to choosing their representatives into cantonal assemblies, and by this indirectly and house of people of higher level, equal voting and general right to representation is breached, while participation of women is unproportional and opposite to positive norms on equality of genders.

In other words, human rights are reduced to ethnic rights. According to solution in force, in elections it is not citizens but nations that vote, and those who are chosen, are not citizens but members of nations or representatives of territory, often ethnically predisposed. Such a conceptual matrix, conserves the condition of war divisions, constitutes geographic-ethnic paradigms, stimulates apartheid and regresses democratic consolidation of state and society. 
According to international standards on human rights, every individual has an equal right to active and passive voting right on the whole territory of the state where he/she lives, and not only to one of these rights on one of its parts and not on others. Solutions in normative part of $\mathrm{B} \& \mathrm{H}$ Constitution political citizen is annulled to the favor of national political representation, as it disregards the fact from preamble of this constitution which identifies also 'citizens' as constitutive subjects which have established B\&H Constitution, so normative provisions of B\&H Constitution recognize only Bosniaks, Serbs and Croats, their collective rights and collective identities in realizing constitutional rights to political representation. According to this 'basic political representation is not citizen, but nation and national identity. Instead of promotion of individual interests and rights of citizens, political interests are shaped based on national interests, and that means collectivity. One-party model of expressive interests of working class, ethnic parties have replaced with expression of collective interests of a nation. ${ }^{123}$.

Pronounced problem of election system is legitimacy of representing the collectivity, with different interpretation of legitimacy, depending on whether the mandate is understood as mandate entrusted to representative or member of constitutive nation. This problem has escalated in 2010 elections when the choice of Croatian member of Presidency of B\&H, was declared as illegitimate by leading parties with Croatian prefix or Croatian national parties, with an argument that Croat elected member of Presidency of $\mathrm{B} \& \mathrm{H}$ chosen by majority of non-Croat votes. Nevertheless, B\&H election system, de iure, does not recognize ethnic votes but ensures the freedom of choice to voters, where such candidates with largest number of votes won, with previous statement of national belonging and positioning on one or two possible lists for member of Presidency of B\&H, become members of presidency from two constitutive nations which are chosen from FB\&H. Opposed to that, de facto, statistically verifiable, Croat member of Presidency of B\&H can be chosen by majority of votes of Bosniaks, without endangering legitimacy of choice of Bosniak member of Presidency of B\&H. In this way election will of members of Croat national voting body is brought into question, even though no legal provisions have been breached. However, election system should ensure trust and satisfaction of political subjects and voting body, and such a huge anomaly determines exactly opposite position on a part of political scene and voting body.

Overall observation, ten years after the Election law came into force, and sixteen changes and amendments which have ensued between 2002 and 2010 have taken place is that with great certainty we can claim that Election Law of B\&H, has had significant role in consolidation of parliamentary democracy in B\&H. However, last two election cycles undoubtedly point to the fact that such election system, 
should necessarily be reformed, harmonized with rulings of international and domestic courts, so that anomalies are reduced to the largest possible extent, as they are too numerous to be annulled by one time cosmetic corrections.

\section{Systematic Precomposition Or Further Disintegration?}

'Rare are examples of constitution of election systems for which we can claim that they are result of careful arrangement based on historical, ethnic, political, cultural, technical and other criteria. ${ }^{24}$ More common are examples where election system is chosen based on two basic reasons:' because political actors do not have enough information and knowledge about consequences of certain types of election systems so they reach for 'political transplantation' of certain election model which is used as blueprint, and second reason is because election actors use their knowledge for promotion of election system which increases their chances in the election race. ${ }^{125}$

As Sartori states, current practices show that re-engineering and choice of election system was especially fundamental and important for (re)constitutioning of democracy in post-socialist societies. In B\&H in the early post-war period election system was established which maintained conditions and social dynamics of present time. Election system is not neutral regulatory mechanism, but is one of the key factors for forming of political scene in the country, which requires period of re-examining. Due to this reason, current election system should be established very quickly as democratic and based on general and equal right of vote, and free and direct elections for all citizens of $\mathrm{B} \& \mathrm{H}$, without regard to their national, religious, territorial and any other belonging.

Concretely, 'B\&H Election system has to contain basic principles of democratic election law: principle of generality, principle of equality, principle of direct, secret and free right to vote. ${ }^{26}$ These principles represent standards of contemporary representative democracy, that is, democratic elections.

'Principle of generality or universality stems from the right that all citizens, without regard to their ethnic, racial, religious, gender, political, social and other differences, enjoy election right under equal conditions, in other words, have equal rights to choose and be chosen. Under the principle of equality in contemporary democratic societies we assume complete equality of parties and candidates. Principle of direct election is expressed in the right of voter to directly choose its representatives. Principle of secrecy represents insurance that no 
pressure is exerted on the voter in any way, either by the representatives of government or from individuals or groups, by which it is required that expressed will of the voters during voting is protected from an insight of the public or other actors of the election process. Finally, principle of freedom of expression assumes the freedom of the voters to form the opinion, which assumes the freedom of speech, press, gathering and association. ${ }^{127}$

B\&H election system has to activate democratic principles prescribed by Constitution and international standards on human rights, in order to be legitimate. Key precondition for its finalization are 'protective democracy'${ }^{128}$, strengthening of government sovereignty, and constitutional and legal precomposition, getting rid of ethnic nationalism, which is generated by constitutional and election legislature, and vice versa.

Implementation of human rights, and in this way right to vote, is obtruded by current Constitution and Election Law of $\mathrm{B} \& \mathrm{H}$ as it provides basis for discrimination. That is why it is of utmost importance that every desired change in Election Law of B\&H has to be accompanied with adequate change in $\mathrm{B} \& \mathrm{H}$ Constitution and vice versa. Due to this reason conceptual changes in Election Law are not so easy move because they encroach into the essence of the $\mathrm{B} \& \mathrm{H}$ Constitution. However, election re-engineering, changes or reforms in election system of some country, are understood as a normal, even welcomed move if they contribute to optimization and are a positive step forward.

Ruling of ECHR in the subject of 'Sejdic\&Finci' established that B\&H Constitution and European convention on protection of human rights and fundamental freedoms are out of step with each other. By this ruling it is ordered to B\&H to harmonize constitutional and legal provisions, especially those which treat equal right of candidacy on elections for House of People of Parliamentary Assembly of B\&H and Presidency of B\&H, to the European Convention on Protection of Human Rights and Fundamental Freedoms. Readjustment of these provisions to Convention encroaches into certain fundamental features of the B\&H election system, which will ultimately lead to re-examining of all other solutions which, due to nature of discrimination can be disputed by new court rulings. The extent of the mentioned court judgments should be used in order to improve election system in one conceptual feature- to ensure equal voting right, and balanced consuming of individual and collective rights of citizens, without regard to ethnic belonging or place of residence. 
Therefore, if we want to achieve improvement in consolidation of parliamentary democracy, ensure progress in democratization, and minimum consensus in state constitutional interest, then it is necessary to bring together these two concepts, appease them by innovative constitutional reforms, reconstruction of election legislative and different political practice, which requires a lot of political wisdom, trust and courage of political elites in $\mathrm{B} \& \mathrm{H}$, but also active and responsible role of international community.

\section{References and Notes}

1. Rainer-Olaf Shultze, Sociology of Elections, in Dieter Nohlen (ed.), "Dictionary of State and Politics" (München, 1996), 115.

2. Pravni leksikon, (Beograd, 1970), 378-379.

3. Rainer-Olaf Shultze, Sociology of Elections, in Dieter Nohlen (ed.), "Dictionary of State and Politics" (München, 1996), 115.

4. Suad Arnautović, Političko predstavljanje i izborni sistemi u Bosni i Hercegovini u XX stoljeću, (Sarajevo, 2009), 274.

5. Ibid, 275.

6. Mirjana Kasapović, Izborni leksikon (Zagreb, 2003), 160.

7. Mirjana Kasapović, Izborni leksikon (Zagreb, 2003), 198.

8. Florian Bieber, „Institucionaliziranje etničnosti: postignuća i neuspjesi nakon ratova u Bosni i Hercegovini, na Kosovu i u Makedoniji”, 25, Forum Bosnae (2004), 31-47, at 36.

9. ECHR, case 27996/06 and 34836/06, Sejdić and Finci v. Bosnia and Herzegovina, Judgment of 22 December, 2009, 28-29.

10. Andrew Heywood, Politics (New York, 2002), 435-436.

11. http://www.izbori.ba/default.asp?col=Statistika

12. Bosnia and Herzegovina General Election 2010, Final Report of Election Observing Mission OSCE/ODIHR, 2010, 6-7.

13. Ibid, 8 .

14. Adis Arapović, „Analisys of Pre-election Rhetoric “, in Bosnia and Herczegovina Generaln elections 2010: Lessons Learned, (Strassbourg, 2011), 79.

15. Bosnia and Herzegovina General Election 2010, Final Report of Election Observing Mission OSCE/ODIHR, 2010, 10.

16. Momir Dejanović, Izbori u BiH 2006. i 2010. godine, (Doboj, 2011), 112.

17. Bosnia and Herzegovina General Election 2010, Final Report of Election Observing Mission OSCE/ODIHR, 2010, 17.

18. http://www.izbori.ba/default.asp?col=Statistika

19. Bosnia and Herzegovina General Election 2010, Final Report of Election Observing Mission OSCE/ODIHR, 2010, 12.

20. Parlamentary Assembly of Council of Europe, Resolution 1839, The political situation in the Balkans, 2011, 2. 
21. Andrew Haywood, Politics (New York, 2002), 221.

22. Ibid, 223.

23. Mirko Pejanović, Politički razvitak Bosne i Hercegovine u postdejtonskom periodu, (TKD Šahinpašić, 2005), 54.

24. Vladimir Goati, et.al., Preporuke za izmenu izbornog zakonodavstva u Srbiji, (Beograd, 2008), 44;

25. Ibid.

26. Dieter Nohlen, Dictionary of State and Politics (München, 1996), 124-125.

27. Suad Arnautović, Političko predstavljanje i izborni sistemi u Bosni $i$ Hercegovini u XX stoljeću, (Sarajevo, 2009), 290-291.

28. Andrew Haywood, Politics (New York, 2002), 144.

\title{
SUMMARY
}

\section{ELECTION SYSTEM OF BOSNIA AND HERZEGOVINA: CATALYST OF UNSUCCESFUL DEMOCRATIZATION}

\author{
Adis Arapovic, Bedrudin Brljavac \\ University of Sarajevo, Bosnia and Herzegovina
}

Bosnia and Herzegovina has faced serious democratic obstacles in the post-war period due to huge shortcomings in its Election Law, among other things. That is, implementation of human rights, and in this way right to vote, is obtruded by current Constitution and Election Law of $\mathrm{BiH}$ as it provides serious basis for discrimination. In fact, present election system in the country is not completely grounded in general, equal and secret right to vote and direct election for all citizens of $\mathrm{BiH}$ who have a voting right. Still, election system has to contain basic principles of democratic election law: principle of generality, principle of equality, principle of direct, secret and free right to vote. These principles represent unavoidable standards of contemporary representative democracy, that is, democratic elections. That's why election system in $\mathrm{BiH}$ has to launch democratic principles prescribed 
by the Constitution and international standards on human rights, in order to be legitimate. Due to this reason conceptual changes in Election Law are not so easy move because they encroach into the essence of the B\&H Constitution. However, election re-engineering, changes or reforms in election system of some country, are understood as a normal, even welcomed step if they will contribute to democratic optimization in the country. Bosnia can not make progress in democratic process if it does not make necessary changes in its election system.

Key words: elections, election legislature, voting rights, democratization, discrimination, Bosnia and Herzegovina. 